\title{
Screening of different insecticides against Helicoverpa armigera (Hubner) (Lepidoptera: Noctuidae) and its effect on yield of tomato crop
}

\author{
Inam Rasheed, Syed Fahad Shah, Jawad Sarwar*, Amjad Usman, \\ Maqsood Shah, Muhammad Usman, Fazli Amin and Numan Nisar \\ Department of Entomology, The University of Agriculture, Peshawar-Pakistan \\ *Corresponding author's email: jsarwaraup@gmail.com
}

Citation

Inam Rasheed, Syed Fahad Shah, Jawad Sarwar*, Amjad Usman, Maqsood Shah, Muhammad Usman, Fazli Amin and Numan Nisar. Screening of different insecticides against Helicoverpa armigera (Hubner) (Lepidoptera:

Noctuidae) and its effect on yield of tomato crop. Pure and Applied Biology. Vol. 8, Issue 1, pp496-502. http://dx.doi.org/10.19045/bspab.2018.700208

\begin{tabular}{llll}
\hline \hline Received: 11/10/2018 & Revised: 29/11/2018 & Accepted: 07/12/2018 & Online First: 12/12/2018 \\
\hline \hline
\end{tabular}

To investigate the comparative efficacy of different insecticides against tomato fruit borer (Helicoverpaarmigera) a study was conducted at Agricultural Research InstituteTarnab, Peshawar during 2016. Experiment was conducted using RCBD design and each treatment was replicated three times. Treatments include Emamectin Benzoate, Radiant, Trycard, Proclaim and control. All the treatments were applied twice with 10 days interval and data was recorded at different time intervals (24hrs, 48hrs, 72hrs, 5days, 7days and 10 days). Results revealed that in both the spray application of insecticides lowest mean of larval population was recorded in the plots treated with Radiant followed by Emamectin Benzoate, Trycard and Proclaim respectively. Control demonstrated the highest mean larval infestation. Similarly, the yield data revealed that the highest mean yield was recorded in the plot treated with Radiant $\left(9452 \mathrm{~kg} \mathrm{ha}^{-1}\right)$ while control showed minimum yield $\left(5608 \mathrm{~kg} \mathrm{ha}^{-1}\right)$. Most elevated percent weight loss (43.82\%) was recorded in check plot and the lowest percent weight loss $(13.35 \%)$ was recorded in the plot treated with Radiant. It was concluded that use of different insecticides not only reduced fruit losses but also increased yield. However, the insecticide radiant is recommended to be used in IPM programs against tomato fruit worm because of their quick biodegradable behavior and availability in the market at economical prices.

Keywords: Helicoverpaarmigerafruit damage;Synthetic Insecticides; Tomato yield

\section{Introduction}

Tomato (Lycopersicon esculentum) Mill placed in family Solanaceae and is one of the most importantproducts throughout the world and is most famous and broadly developed vegetables on the planet. The highest productivity of tomato is brought about by Spain having 66.81 tha $^{-1}[1]$. Tomato has put second in rank after potato. It is the most essential vegetables that individuals used to develop it in home gardens and by the market cultivators. Mostly it is utilized in a fresh and 
processed form while in Pakistan people generally use it as a salad. Tomato is a decent source of vitamins A, B and C. Furthermore it helps in healing of wounds because of antimicrobial properties [2].

In Pakistan farmers grow the tomato crop an area of 57.4 thousand hectares having an average yield of $9719.51 \mathrm{~kg}$ per hectare. The normal production of tomatoes was observed 10.1 tons for each hectare [3]. The insect pests damage the crop in various stages and affect the quality and quantity of fruit adversely. Tomato crop has some serious insect pests which damage the yield of tomato very badly i.e, white flies, cutworms, thrips, aphids and fruit worm. In Pakistan the production of tomato is very low as compare to other countries. The production of tomato is very low because of many reasons among them the most important reason is insect pests [4].

Similar to all soft vegetables tomato is too prone to the insect pests and disease attack because of its tenderness and softness. It is attacked by a number of pests but tomato fruit borer is one of the major pest causing economic yield loss to the farmers, yield loss recorded up to $35 \%$ in tomato [5]. Tomato fruit borer is the most damaging pest of tomato, which is generally known as gram pod borer, american bollworm and tomato fruit borer. Young larvae feed only on foliage, flower buds and flowers, while the later instars of these borers drill into fruit and render them unmarketable [6].

Different management practices are used to minimize the insect pest infestation. The first choice is the total pest population decline, while the second one is saving the main crop at its certain time by the introduction of cultural practices i.e trap crops, deep ploughing and mechanical damage. But chemical control is the most effective management technique for pestscontrol, which is used in each and every crop by the farmers because of its ease of access, effortless in use and high return ratio [7]. Thus the objectives of this study are to observe the efficacy of different insecticides against $H$. armigera (Hubner) on tomato crop and to determine the yield of tomato crop after the application of different insecticides.

\section{Materials and methods}

Study was carried out to determine efficacy of different insecticides against tomato fruit borer $H$. armigera on tomato crop at Agriculture Research Institute, Tarnab Peshawar (Khyber Pakhtunkhwa, Pakistan) in 2016. Experiment was performed in Randomized Complete Block Design (RCBD) with five treatments each with three replications (Table 1). Size of plot was 4.5 $\times 21 \mathrm{~m}$. Plant to plant and row to row distances were kept $45 \mathrm{~cm}$ and $60 \mathrm{~cm}$ respectively and variety of tomato under trial was $\mathrm{F}_{1}$ hybrid.

Each treatment was replicated three times. Spray applications of all the tested insecticides were applied at the time of pest occurrence and was repeated with interval of 15 days. First application was applied at the occurrence of pest while the second application was applied with 15 days interval. Data was recorded on randomly selected 6 plants plot $^{-1}$ and the observations on larval population, \% weight loss and tomato yield $\left(\mathrm{kg} \mathrm{ha}^{-1}\right)$ was recorded. Larval population of tomato fruit worm was recorded 24 hours before spray application and post treatment count was taken as (24, 48 and 72) hours and (5, 7 and 10 days) after application. Collected data was subjected to ANOVA and means was separated using LSD test (Statistix@8.1). The following formulas were used to calculate percent weight loss, tomato yield and increase over control.

\section{Percent weight loss}

Percent weight loss was recorded in all the plots separately by using the following formula.

Percent weight loss $=$ Weight of damaged fruits/Total weight of tomato fruits $\mathrm{x} 100$ 


\section{Total tomato yield}

Total tomato yield was recorded for all the plots, yield was then recorded to as $\mathrm{kg} \mathrm{ha}^{-1}$ by using the following formula;

Yield $\left(\mathrm{kg} \mathrm{ha}^{-1}\right)=$ Total weight of Tomato plot $1 /$ Plot size $\left(\mathrm{m}^{2}\right)$ x 10000

Increase in yield over control $(\%)$ $\%$ increase over control $=\mathrm{A}-\mathrm{B} / \mathrm{B} \times 100$ $\mathrm{A}=$ Total Yield of a Treated Yield $\mathrm{B}=$ Yield of control plot

Results and discussion Effect of different insecticidal application on the larval population of Helicoverpa armigera

Table 2 revealed that insecticidal application had a significant impact in reducing larval population of tomato fruit borer in comparison to control. However no significant difference was recorded among treated plots. Data recorded after $1^{\text {st }}$ spray (24h, 48h, 72h, 5 days, 7 days and 10 days) illustrated that Radiant was the most efficient insecticide against the larvae of tomato fruit borer $(1.52,1.32,1.04,0.59,0.70$ and 1.04 larvae/plant), followed by Emamectin Benzoate (1.61, 1.44, 1.22, 1.00, 1.09 and 1.31 larvae/plant), Trycard (1.67, 1.53, 1.30, $1.21,1.31$ and 1.53 larvae/plant), while Proclaim appeared to be the least effective insecticide $(1.77,1.56,1.47,1.46,1.51$ and 1.71 larvae/plant) but showed appreciating results in relation to the control.

Similar trend in the larval population has been observed after $2^{\text {nd }}$ application. Radiant was the most efficient insecticide against the larvae of tomato fruit borer $(1.33,1.28,1.07$, 0.85, 0.66 and 0.44 larvae/plant), followed by Emamectin Benzoate (1.42, 1.39, 1.20, 1.00, 0.93 and 0.79 larvae/plant), Trycard (1.72, 1.49, 1.37, 1.19, 1.04 and 0.99 larvae/plant), while Proclaim found to be the least effective insecticide (1.92, 1.70, 1.50, 1.33, 1.20 and 1.07 larvae/plant) but showed appreciating results in relation to the control. Effective control of $H$. armigera with the aid of different insecticides has also beenreported by many researchers. [8] Tested emamectin benzoate against brinjal fruit borer and reported lower infestation $(40.1 \%)$. [9] Reported the same effect of Radiant against tomato fruit borer as our study demonstrates. It was recorded $73 \%$ reduction in tomato fruit borer larvae infestation in radiant treated plot and concluded that radiant has best results against $H$.armigera. [10] Experimented different chemicals to control the population density of $H$. armigera. Results depicted that cypermethrin can effectively control the pest and aid in greater yield. [11] Applied different chemicals in a tomato field against $H$. armigera and observed that chemical control effectively reduce the infestation of $H$. arimgera in the field. [12] Applied combination of pesticides and plant extracts against $H$. armigera in tomato field. They found that application of insecticides and plant extracts greatly suppress the density of $H$. armigera and increase the production capacity resulting in the wellbeing of farmer. [13] Examined the infestation variance of $H$. arimgera on different crops and reported that $H$. armigera is destructive pest that can result in significant yield losses. To minimize losses from $H$. armigera he suggested that bio-control agents and chemical control should be used. However the present study shows that all the treatments applied during the course of experiment were statistically not significant from each other and provided synchronized results, yet radiant is the most appropriate insecticide because of its effectiveness in minimizing $H$. armigera infestation and less persistent in the environment as compared to the other insecticides.Similar results were reported by [14] who revealed that spinetoram (radiant) has short residual period of 11 days in reference to other treatments. [15] Reported that cypermethrin degradation takes upto 16 days. 
Table 1. Treatment details

\begin{tabular}{|c|c|c|}
\hline Treatments & Active Ingredients & Recommended dose \\
\hline Emamectin Benzoate, 19\% EC & Emamectin & 2cc per liter of water \\
\hline Radiant, 20\% EC & Spinetoram & $0.8 \mathrm{cc}$ per liter of water \\
\hline Trycard, 10\% EC & Cypermethrin & 2cc per liter of water \\
\hline Proclaim, 19\% EC & Emamectin & 2cc per liter of water \\
\hline
\end{tabular}

Table 2. Effect of different insecticidal application on the larval population of $H$. armigera

\begin{tabular}{|c|c|c|c|c|c|c|c|c|c|c|c|c|c|c|}
\hline \multirow{3}{*}{ Treatments } & \multicolumn{14}{|c|}{ H. armigera Larval population } \\
\hline & \multirow{2}{*}{$\begin{array}{c}\text { Before } \\
1^{\text {st }} \\
\text { Spray } \\
\end{array}$} & \multicolumn{6}{|c|}{ After $1^{\text {st }}$ Spray } & \multirow{2}{*}{$\begin{array}{c}\text { Before } 2^{\text {nd }} \\
\text { Spray }\end{array}$} & \multicolumn{6}{|c|}{ After $2^{\text {nd }}$ Spray } \\
\hline & & 24Hrs & 48 Hrs & $72 \mathrm{Hrs}$ & 5 days & 7 days & 10 days & & $24 \mathrm{Hrs}$ & 48 Hrs & $72 \mathrm{Hrs}$ & 5 days & 7 days & 10 days \\
\hline $\begin{array}{c}\text { Emamectin } \\
\text { Benzoate }\end{array}$ & 1.94 & $1.61 \mathrm{~b}$ & $1.44 \mathrm{~b}$ & $1.22 \mathrm{~b}$ & $1.00 \mathrm{bc}$ & $1.09 \mathrm{bc}$ & $1.31 \mathrm{bc}$ & 1.59 & $1.42 \mathrm{~b}$ & $1.39 \mathrm{bc}$ & $1.20 \mathrm{bc}$ & $1.00 \mathrm{bc}$ & $0.93 \mathrm{bc}$ & $0.79 \mathrm{c}$ \\
\hline Radiant & 2.03 & $1.52 \mathrm{ab}$ & $1.32 \mathrm{~b}$ & $1.04 \mathrm{~b}$ & $0.59 \mathrm{c}$ & $0.70 \mathrm{c}$ & $1.04 \mathrm{c}$ & 1.99 & $1.33 \mathrm{c}$ & $1.28 \mathrm{c}$ & $1.07 \mathrm{c}$ & $0.85 \mathrm{c}$ & $0.66 \mathrm{c}$ & $0.44 \mathrm{~d}$ \\
\hline Trycard & 2.01 & $1.67 \mathrm{~b}$ & $1.53 \mathrm{~b}$ & $1.30 \mathrm{~b}$ & $1.21 \mathrm{~b}$ & $1.31 \mathrm{~b}$ & $1.53 \mathrm{bc}$ & 2.06 & $1.72 \mathrm{bc}$ & $1.49 \mathrm{bc}$ & $1.37 \mathrm{bc}$ & $1.19 \mathrm{bc}$ & $1.04 \mathrm{~b}$ & $0.99 \mathrm{bc}$ \\
\hline Proclaim & 1.94 & $1.77 \mathrm{ab}$ & $1.56 \mathrm{~b}$ & $1.47 \mathrm{~b}$ & $1.46 \mathrm{~b}$ & $1.51 \mathrm{~b}$ & $1.71 \mathrm{~b}$ & 2.12 & $1.92 \mathrm{~b}$ & $1.70 \mathrm{~b}$ & $1.50 \mathrm{~b}$ & $1.33 \mathrm{~b}$ & $1.20 \mathrm{~b}$ & $1.07 \mathrm{~b}$ \\
\hline Control & 1.98 & $2.29 \mathrm{a}$ & $2.44 \mathrm{a}$ & $2.94 \mathrm{a}$ & $3.02 \mathrm{a}$ & $3.10 \mathrm{a}$ & $3.38 \mathrm{a}$ & 3.38 & $3.39 \mathrm{a}$ & $3.44 \mathrm{a}$ & $3.45 \mathrm{a}$ & $3.66 \mathrm{a}$ & $3.66 \mathrm{a}$ & $3.76 \mathrm{a}$ \\
\hline LSD value & & 0.59 & 0.48 & 0.44 & 0.54 & 0.53 & 0.66 & & 0.52 & 0.37 & 0.42 & 0.38 & 0.34 & 0.26 \\
\hline
\end{tabular}

Mean in column followed by dissimilar letters are statistically different at $\alpha=0.05$ (LSD Test) 
Marketable Yield, Infested Yield and Percent weight loss of tomato fruit

Table 3 showed the percent weight losses in different treatments. Results revealed that all the insecticides have significant difference with the control. Result further showed that the highest percent weight loss was recorded in control $(43.82 \%)$, while the plot treated with Radiant showed the lowest percent weight loss $(13.35 \%)$. Present study also showed that plots with lowest larval infestation gave higher marketable yield. As

Table 3. Marketable Yield, Infested Yield and \% weight loss of tomato fruit affected by different insecticides

\begin{tabular}{|c|c|c|c|}
\hline Treatments & $\begin{array}{c}\text { Marketable yield } \\
\left(\mathbf{k g ~ h a}^{-\mathbf{1}}\right)\end{array}$ & $\begin{array}{c}\text { Infested yield } \\
\left(\mathbf{k g ~ h a}^{-\mathbf{1}} \mathbf{)}\right.\end{array}$ & \% weight loss \\
\hline Emamectin Benzoate & $6878 \mathrm{~b}$ & $1444 \mathrm{~d}$ & $17.90 \mathrm{bc}$ \\
\hline Radiant & $8217 \mathrm{a}$ & $1233 \mathrm{e}$ & $13.35 \mathrm{c}$ \\
\hline Trycard & $6243 \mathrm{c}$ & $1621 \mathrm{c}$ & $19.62 \mathrm{bc}$ \\
\hline Proclaim & $5785 \mathrm{~d}$ & $1763 \mathrm{~b}$ & $24.08 \mathrm{~b}$ \\
\hline Control & $3103 \mathrm{e}$ & $2504 \mathrm{a}$ & $43.82 \mathrm{a}$ \\
\hline LSD value & 1110.4 & 233.17 & 6.78 \\
\hline
\end{tabular}

Means in columns followed by dissimilar letters are statistically different at $\alpha=0.05$ (LSD Test)

\section{Total tomato yield $\left(\mathrm{kg} \mathrm{ha}^{-1}\right)$}

Average yield of tomato $\left(\mathrm{kg} \mathrm{ha}^{-1}\right)$ was recorded in different plots treated with different insecticides, showed in (Table 4). Results revealed that all the insecticidal treatments have significant difference with the control. Data in the table revealed that maximum yield of tomato was observed in the plot treated with Radiant $\left(9450 \mathrm{~kg} \mathrm{ha}^{-1}\right)$ while check plot showed $\left(5607 \mathrm{~kg} \mathrm{ha}^{-1}\right)$ which is minimum yield among all the plots.

Table 4. Effect of different insecticides on tomato yield

\begin{tabular}{|c|c|c|}
\hline Treatments & Yield $\mathbf{( k g ~ h a}^{-1}$ ) & \% increase over control \\
\hline Emamectin Benzoate & $8322 \mathrm{~b}$ & 48.42 \\
\hline Radiant & $9450 \mathrm{a}$ & 68.53 \\
\hline Trycard & $7864 \mathrm{~b}$ & 40.25 \\
\hline Proclaim & $7548 \mathrm{~b}$ & 34.61 \\
\hline Control & $5607 \mathrm{c}$ & - \\
\hline LSD $_{(0.05)}$ Value & 1006.7 & \\
\hline
\end{tabular}

Means in columns followed by dissimilar letters are statistically different at $\alpha=0.05$ (LSD Test)

Conclusion and recommendations

All the tested insecticides showed effective control of tomato fruit worm and provided higher yield of tomato in comparison to
Present experiment was carried on a single tomato genotype, so the variation in the percent increase in weight of tomato over was possibly due to use of different pesticide. Our results are in coherence with [19] who registered that with application of insecticides effectively increase the yield. [20] Also revealed that management of field with various insecticides can enhance the production of tomato.

control. However maximum yield production was registered for radiant followed by emamectin benzoate, trycard and proclaim. Furthermore radiant is cheap and easily 
biodegradable in reference to other tested chemicals. It is therefore recommended to be used in IPM programs to reduce infestation of tomato fruit worm.

\section{Authors' contributions}

Conceived and designed the experiments: I Rasheed \& SF Shah, Performed the experiments: I Rasheed, A Usman \&NNisar, Analyzed the data: M Usman\&F Amin, Wrote the paper: J Sarwar\& M Shah.

\section{References}

1. National Horticultural Board (2011). Annual Reportpp 170-177.

2. Baloch FA (1994). Vegetable Crops. In: Horticulture. National Book Foundation, Islamabad pp 508.

3. Anonymous (2013). Agricultural Statistics of Pakistan 2011-12. Govt. of Pakistan, Ministry of Food.

4. Hoffmann H, Hadie D\& Burt J (2007). Tomato pests in the home garden and their control. Dept. Agric. Australia. Garden Note 34: 82-88.

5. Dhandapani N, Shelkarand UR \&Murugan M (2003). Bio-intensive pest management (BIPM) in major vegetable crops: an Indian perspective. $J$ Food Agric Environ 1(2): 330-339.

6. Tiwari GC\&Krishanmurthy PN (1984). Yield loss in tomato caused by fruit borer. IndAgriSci54(4): 341-343

7. Yaghoub F \&Sedaratian A (2013). Integrated management of Helicoverpaarmigera in soybean cropping systems. In: Soybean pest resistance, editor. Hany A. ElShemy.pp.245-255.

8. Sajjad A, Mari JM, Khanzada MA\&Ullah F (2015).Efficacy of insecticides against infestation of brinjalfruit borer, LeucinodesorbonalisGuenee (Pyralidae: Lepidoptera). JEntomolZool Studies 3(3): 292-295.

9. Babar TK, Hasnain M , Aslam A, Ali Q, Ahmad KJ, Ahmad A \&Shahid M
(2016). Comparative bioefficacy of newer insecticides against tomato fruit borer, Helicoverpaarmigera (Hubner) on tomato crop under field conditions. PakEntomol 38(2): 115-122

10. Sohail A, Khurram Z\&Naeem RS (2004). Validation of chemical control of gram pod borer, $H$. armigera with new insecticides. Ind J Plant Prot 4: 41-49.

11. Ghosal A, Chatterjee ML \& Manna D (2012).Studies on some insecticides with novel mode of action for the management of tomato fruit borer (Helicoverpaarmigera Hub.). J Crop Weed 8(2): 126-129.

12. Rizvi SAH \&Jaffar S (2015). Efficacy of some selected chemical insecticides and bio-pesticides against Helicoverpaarmigera under the agro climatic condition of Gilgit Baltistan.Pak J Entomol Zool 3(4): 5052.

13. Abbas S, Tahir MJ, Naeem A, Sarfraz AS, Rafiq M \& Ahmad MS (2015). Effectiveness of Chlorantraniliprole, Indoxacarb, Fluendiamide, Spintoram, Thiamethaxim, Emamectin Benzoate and Lufenuron in Pakistan environment. J Phyto 43: 577-583.

14. Visnupriya $\mathrm{M}$ \&Muthukrishnan $\mathrm{N}$ (2017). Persistence Toxicity and Field Evaluation of Green Insecticide Spinetoram 12 SC w/v (11.7\% w/w) against HelicoverpaarmigeraHubner on Okra. IntJCurrMicrobiol App Sci 6(11): 2547-2555.

15. Walker MH\& Keith LH (1992). EPA's Pesticide Fact Sheet Database. Lewis Publishers, Chelsea, MI.

16. Hasan W, Chhibber RC \&Singh CP (2016). Effect of Indoxacarb against Tomato Fruit Borer (HelicoverpaarmigeraHub.) and Phytotoxicity to tomato Plants.Adv Plant AgriRes 3(2): 1-4. 
17. Mahla MK, Lekha, Singh V, Swami H \&Choudhary RS (2017). Efficacy of different insecticides against pest complex of tomato and effect on their natural enemies. J EntomolZool Studies 5(5): 229-234.

18. Usman A, Ali MI, Shah M, Amin F \&Sarwar J (2018). Comparative efficacy of indigenous plant extracts and a synthetic insecticide for the management of tomato fruit worm (HelicoverpaarmigeraHub.) and their effect on natural enemies in tomato crop. Pure ApplBiol 7(3): 1014-1020.

19. Utti PS (2017). Bio-efficacy of newer insecticides against Fruit Borer (Helicoverpa armigera $\mathrm{Hb}$.) of Tomato. M.Sc (Hons) Thesis. Dept. of Entomol, Coll. Agri. Indore, pp 51.

20. Kumar V, Kakkar G, McKenzie LC, Seal D\& OsborneL (2013). An Overview of ChilliThrips, Scirtothrips dorsalis (Thysanoptera: Thripidae). Biol, Distri and Manag 53-77. 